\title{
English Basecamp: An Alternative Learning Method for Enhancing Speaking Skill (A Case Study in Kampung Inggris, Pare, Kediri, East Java)
}

\author{
Muhamad Ahsanu, Rizki Februansyah \& R. Pujo Handoyo \\ English Department, Faculty of Social and Political Sciences, Jenderal Soedirman University \\ Ahsanu.muhamad@yahoo.com
}

\begin{abstract}
Learning method is a vital element in all learning process. An effective learning method will yield the learning output as expected by the educational institution. There are many learning methods applied in Indonesia. One of them is classical method in which students and teachers are in the classroom and the teachers function as instructors. The technique which is most frequently used is lecturing method accompanied with practice, presentation and evaluation. Those techniques are worth implementing in some conditions. Yet, the fact shows that the conventional techniques applied in classroom do not give optimum result, particularly in verbal language learning. This research was aimed at disclosing further on the basecamp method employed in English courses in Kampung Inggris, Pare, Kediri. The focuses of this research were the process of basecamp learning, the effectiveness of basecamp method and the obstacles in its implementation. This research belongs to descriptive qualitative using survey method. The populations were the participants of English courses in three English courses elected by purposive sampling. The techniques of data collection were observation, interview, questionnaire and test. The result of the research showed that there was a significant improvement of the participants' speaking skill after joining the course for a month. This conclusion indicated that English basecamp is an effective method and can be used as an alternative method in English learning particularly speaking.
\end{abstract}

Keywords: learning method, basecamp, improvement, effective

\section{Introduction}

English language learning is a long and complex process. This activity requires physical, intellectual and emotional endeavor due to the differences in grammars, lexicons, and cultures. Moreover, there are many variables involved in the activity including learning methods, learning media and learning environment which do influence the achievement of English learners.

Based on the researchers' observation, it was found that most of university students majoring either in English or another discipline have poor English. This phenomenon encouraged the researchers to figure out an alternative learning method which is more effective to improve students' English competence, particularly the verbal English. One of the learning methods appealing to be scrutinized is basecamp method which has been applied in English teaching process at Kampung Inggris (English Village), Pare sub district, Kediri regency, East Java.

The research was conducted to address the following three problems: how was the learning process of verbal English employing basecamp method in Kampung Inggris, Pare sub district, Kediri Regency, East Java? How effective was the basecamp method in improving the students' verbal English competence? What were the obstacles in the process of learning verbal English using basecamp method?

\section{Theoretical Framework}

With reference to Bloomfield's theory of behaviorism, language behavior is perceived as an effective language behavior as a response towards the stimulus. If a certain response is stimulated repeatedly, it turns into a conditioned habit. Hence, language learners will produce conditioned linguistic responses (Brown, 2008:29). The proponent of this theory, Skinner who is famous with his Operant 
Conditioning theory, i.e. conditioning to make organism, to give responses, or operant (in the form of sentences or utterances) spontaneously which is maintained and trained with certain stimulus (ibid).

\section{Teaching Strategy}

Basically, teaching has a universal feature comprising three main factors: teacher, material and student. A successful teaching needs a teaching strategy. Phrased differently, a teaching strategy is a tool used to transfer fact, idea, concept, expertise and behavior into the learners' mindset and conduct (Freiberg and Driscoll, 1992; 59). With reference to those teaching experts, there are some teaching strategies, e.g. lecturing, discussion and question and answer, grouping and role-play (ibid: 175-321).

Lecturing can be applied in all types of learning and a strategy focusing on the transfer of ideas to other people (students).Discussion and question and answer is a unique strategy in the learning and teaching process since with the question and answer received by a student, a teacher can know directly the comprehension level of the student which can urge the teacher to modify his/her teaching. A grouping strategy can be defined as a way to organize students to make the process of knowledge transfer runs smoothly. In the role-play strategy, learner or student can be directly involved in the content development, comprehension, expertise, and conduct.

\section{Verbal English}

Speaking skill in a foreign language requires certain ability, including a correct pronunciation, word stress and intonation, and the expression of idea systematically. In addition, a language user must be able to speak in any situations and conditions and to use the effective communication strategies. For
English verbal learner, the right method is the method emphasizing on the verbal communication as a media in language acquisition, a practice of memorizing and habit formation (Howatt in Bygate, 2006:14). The more someone practices speaking, the more fluent his/her verbal competence will be. The learning process like this uses a communicative approach which means that learning activity offers chances to the learner to use English freely regardless the grammar is.

\section{Methodology}

This research was held starting from May to August 2011 that took place in Kampung Inggris (English Village), Pelem village, Pare Sub-district, Kediri Regency, East Java. The research data was gained from three different research courses.

In this research, the populations were the course participants in Pare, Kediri. According to Borg and Gall (1979:178), the samples chosen are supposed to represent the population decided earlier in this research-basecamp participant. The sample taking method was purposive sampling owing to the researcher's considerations (Sugiyono, 2008:85).

\section{Discussion}

\subsection{Interview Result}

One of the data collection methods used in this research was interview that involved both basecamp instructors and students. The interview materials to the instructors included the learning materials that they taught, educational background, teaching method, evaluation method, and the like. Meanwhile, the interview materials to the students comprise students' motivation to come to learn English to Pare, their educational backgrounds, the problems that they encountered in learning English, their impressions 
toward basecamp programs, and their critiques and suggestions for the programs.

The instructors used varied teaching methods especially for regular class. One of the methods used was "repetition and drilling". In the words of the instructors, this method was quite appropriate with the learning atmosphere in the basecamp since the method was focused on the facet of understanding and memorization. Henceforth, the students were trained to memorize some common words and phrases on daily basis.

\subsection{Questionnaire Result}

The students had positive impressions towards the learning process in the course and in the basecamp. They stated that the teaching learning method and processes in the basecamp that they underwent were effective in enhancing their verbal English competence. This is clearly seen in the students' opinion in which most of the respondents admitted and valued highly that learning materials were very good and they believed that the English course supplement with the basecamp learning method had a great influence on the improvement of their English.

\subsection{Observation Result}

The observation was conducted at the beginning and the end of the program. Three basecamps of different courses were observed when they were conducting after-Mahrib (evening) and after Subuh (dawn) sessions. The focuses of observation were: 1 . The instructor, 2. The participants (students), 3. The learning method, 4. The learning materials, 5. Teaching media and 6. Learning atmosphere.

Generally the instructors in all three basecamps had met standard requirements in terms of English skills, material mastery, and teaching techniques. Most of them were not specifically educated in English, but their practical skill were not less than the English academy graduates' because they practiced a lot and joined English courses where they absorbed and adopted various teaching methods. Some of them were the graduates of Pare English courses.

In terms of teaching methods, the instructors followed the teaching standard in basecamp which includes presentation, practice and production. They used primarily repetition and drilling method in which they guided the students to read and pronunce some words, phrases and daily expressions repeatedly until the students acquired them. Beside drilling, the basecamp also used presentations, group discussions and debates. Not only do these method improved their English, but also they were believed to improve the students' confidence.

\subsection{Test Result}

The followings are the results of speaking tests given to students before joining basecamp program.

Table 1: Score of Speaking Pre-test

\begin{tabular}{|l|l|l|l|l|l|l|l|l|l|l|}
\hline Student & $\mathrm{X} 1$ & $\mathrm{X} 2$ & $\mathrm{X} 3$ & $\mathrm{X} 4$ & $\mathrm{X} 5$ & $\mathrm{X} 6$ & $\mathrm{X} 7$ & $\mathrm{X} 8$ & $\mathrm{X} 9$ & $\mathrm{X} 10$ \\
\hline Score & 20 & 20 & 20 & 32 & 20 & 20 & 44 & 20 & 68 & 60 \\
\hline
\end{tabular}

Table 2: Score of Speaking Post-test

\begin{tabular}{|c|c|c|c|c|c|c|c|c|c|c|}
\hline tudent & $\mathrm{X} 1$ & $\mathrm{X} 2$ & $\mathrm{X} 3$ & $\mathrm{X} 4$ & $\mathrm{X} 5$ & $\mathrm{X} 6$ & $\mathrm{X} 7$ & $\mathrm{X} 8$ & $\mathrm{X} 9$ & $\mathrm{X} 10$ \\
\hline Score & 52 & 52 & 52 & 64 & 52 & 44 & 72 & 52 & 84 & 80 \\
\hline
\end{tabular}

In table 1 above, it is shown that the basic Speaking skill of the students' before basecamp program was poor with an average score 32 (1-100 scale). Only two students got score 68 and 60. During basecamp program, they learned English under the guidance of a dormitory head which also acted as language facilitator. For a certain period of time they practiced English in the morning, afternoon and evening. After a month, their speaking skill was tested again.

Table 2 shows that students' speaking scores increased in all aspects of speaking. In general, the 
average score rose from 32 to 64 , or $100 \%$. This increase was attributed to the learning process (treatment) which was done intensively by students who in majority had high motivation, supported by conducive atmosphere through implementation of basecamp/dormitory program. This was surprising because in only one month it gained an improvement which is difficult to achieve with conventional method (teacher-centered learning). Basecamp is a model that emphasizes the symbiotic/reciprocal interaction between facilitators and students, and between students themselves in a friendly atmosphere.

\section{Conclusion}

The English learning process in basecamp was conducted twice a day i.e. early in the morning after Subuh (dawn) prayer and evening after Maghrib (evening) prayer. The learning strategies were various, such as lecturing, question and answer, grouping, presentation, debate and role-play. Another frequently used technique was drilling whose aim was to enable students to memorize some English expressions. This technique was regarded more effective than learning grammar first as practiced in most schools. The distinctive feature of this method is its natural, home-like learning atmosphere in terms of location, time, method, rules and interaction. In addition, the students had more chance to interact with their instructors without fear. This democratic atmosphere did sustain students' motivation and participation in basecamp. The learning process using the method was proven effective since the results of post-test indicated a significant improvement with respect to the students' oral competence. This is because the basecamp method shaped students' mindset and habit which are very necessary in language learning.

\section{References}

1) Borg, W.R. dan Gall, M.D. (1979). Educational Research ( $3^{\text {rd }} E d$.). New York: Longman Inc.

2) Brown, H.D. (2004). Language Assessment, Principles and Classroom Practices. New York: Pearson Education Inc

3) _ (2007). Principles of Language Learning and Teaching $\left(4^{\text {th }} E d\right)$. New York: Addison Wesley Longman Inc

4) Bryman, A. (2004). Social Research Methods (2 $2^{\text {nd }}$ Ed.). Oxford: Oxford University Press

5) Carter, R. and Nunan, D. (2001). Teaching English to Speakers of Other Languages. Cambridge: Cambridge University Press

6) Creswel, John W. (1998). Qualitative Inquiry and Research Design: Choosing Among Five Traditions. London: SAGE Publications

7) Degeng, I Nyoman S. (2005). Belajar dan Pembelajaran. Malang: Lab TPFIP UNM

8) Freiberg, H. Jerome dan Driscoll, Amy. (1992). Universal Teaching Strategies. Boston: Allyn and Bacon

9) Gay, L.R. (1987). Educational Research. Ohio: Merrill Publishing Company

10) Harmer, J. (2007). The Practice of English Language Teaching. England: Longman

11) Richards, J. C. (2001). Curriculum Development in Language Teaching. Cambridge: Cambridge University Press 